\title{
CREATIVE THINKING CURRICULUM INFUSION FOR STUDENTS OF TEACHERS' EDUCATION PROGRAM
}

\author{
${ }^{1}$ Mingchang Wu, ${ }^{2}$ Ibnu Siswanto, ${ }^{3}$ Wardan Suyanto, ${ }^{4}$ Yoga Guntur Sampurno, ${ }^{5}$ Weijen Tan \\ ${ }^{1,5}$ Graduate School of Technological \& Vocational Education, National Yunlin University of Science and Technology \\ Taiwan, Taiwan \\ 2,3,4 Department of Automotive Engineering Education, Universitas Negeri Yogyakarta, Indonesia \\ E-mail: wumc@yuntech.edu.tw
}

\begin{abstract}
Creative thinking is consistently approved as a crucial competency for people to productively learn and succeed in this globalization and competition era. This article discusses the definition, major factors, and processes of creative thinking, and analyzes its improvement strategies. Furthermore, a curriculum infusion was proposed as an effective strategy to improve individual's creative thinking in the universities, especially for teachers' education program. The process of creative thinking curriculum infusion's development consists of the following steps: (1) development of the creative thinking curriculum objectives, contents, and teaching strategies (2) selection of the existing courses to integrate creative thinking contents, and (3) implementation of creative thinking curriculum infusion model. This article finally suggests universities which provide teachers' education program to extensively (1) integrate creative thinking contents into regular courses offered in the universities, (2) implement various creative thinking improvement strategies to deliver creative thinking contents, and (3) utilize a creative thinking self-assessment scale to measure students' creative thinking. Moreover, a creative thinking curriculum infusion model as the recommended methods to improve learners' creative thinking should be implemented to attain its empirical validation.
\end{abstract}

Keywords: creative thinking, curriculum infusion, teachers' education program

\section{INTRODUCTION}

The global environment is becoming increasingly more turbulent and competitive because of the radical and continuous change in global mobility (Hendrickson et al., 2013; Knight, 2003), rapid knowledge advancement (Dagget, 2014; Petrie, 2011), social transformation and democratic atmosphere evolution (Groff, 2013) and industrial revolution (Baygin et al., 2016). Subsequently, it is important to prepare the students to live, to work, and to be successful in this challenging situation (Ford \& Gioia, 2000; Karpova et al., 2011). Moreover, what kind of competencies should be taught for the youngsters to succeed in their future career.

The American Management Association (AMA) has been surveyed the skill required for entry-level jobs in industry with totally 2.115 managers and other executives as subjects of the study. The result exposed that critical thinking or problem solving, communication, collaboration, and creativity or innovation become more imperative to industries (AMA, 2010). Creative thinking as a fundamental component of those crucial skills corresponds with some subsequent studies which identify creative thinking as valuable skills for facilitating individual to succeed in the workplace, family life, and citizenship (Hilton, 2015), attain higher academic achievement (Bolandifar \& Noordin, 2013), and accomplish higher personal and public achievement (Runco et al., 2010).

At present, creative thinking is important as many countries develop their national economy through innovative production processes and new products which have greater reliance on the intellectual capital rather than natural resources (McKinsey Global Institute, 2012; Sepehrdoust \& Shabkaneh, 2015). For instance, OECD (2007) data report shows that the 4 most significant economies (Brazil, Russia, India, \& China) doubled their high-tech products export from $15 \%$ in 1996 to more than $30 \%$ in 2004 and decrease their low-tech products export from $34 \%$ in 1996 to less than 
$24 \%$ in 2004. It implies that national economic growth highly relies on innovative industries resulting from their citizens' creativity.

Students with creative thinking are approved to generate in-depth knowledge through effective learning (Sdouh, 2013), which consequently supports them to initiate an innovative knowledge, ideas, or products. Individuals such as Bill Gates, Steve Jobs, and Mark Zuckerberg are very competent in their professional fields which lead them to generate innovative ideas and creating Microsoft Company, iPhone, and Facebook, respectively. It also could assist people to solve problems with unique approaches while encountering challenges (Gibson, 2015). For instance, Elon Musk the founder of Pay Pal also shows that unusual approaches might be better than traditional way to circulate money, innovation changes the world.

As an essential proficiency to solve problems ranging from individual to world eminent difficult situation and to facilitate people to be successful in their life, is it possible to improve individuals' creative thinking? Previous studies conducted by Pishghadam \& Mehr (2011) and Yasin \& Yunus (2014) declaimed that there is a significant relationship between students' performance and learning activities with their creative thinking. Furthermore, Wu et al. (2017) concluded that students' affective creativity, imagination, and self-efficacy collaboratively affect students' creative thinking which leads to support students' academic achievement improvements.

Hsiao et al. (2014) also revealed that individual's creativity is effectively nurtured through digital game-based learning. Moreover, some methods were recognized as an effective approach to effectively improve students' creative thinking including brainstorming (Sdouh, 2013), mathematics learning management models (Sriwongchai et al., 2015), thinking skills-based instructional strategies (Alghafiri \& Ismail, 2014), argumentation - based science learning (Demir \& Isleyen, 2015), and problem solving (Nozari \& Siamaian, 2014).

Subsequently, it seems that creative thinking is not necessarily an innate gift, but it's an ability which could be improved through effective materials and approaches. What is more, a curiosity emerges as how to improve individual creative thinking, especially in the educational setting?

\section{METHOD}

This paper used a systematic literature review, including selected the crucial topic, collected the literatures, analyzed and synthesized the literatures (Cronin et al., 2008). It discussed the improvement of individual's creative thinking, focusing on its definitions and major contents, and the process of initiating creative thinking, and finally proposes the creative thinking curriculum infusion model to improve university students' creative thinking.

\section{RESULTS AND DISCUSSION}

Creative thinking is considered as one of the most important competency in the $21 \mathrm{st}$ century (AMA, 2010; Flynn, 2014). Creative thinking has been defined as the ability that assists people to think divergently and find the uncommon solutions for solving problems (Guilford, 1950; Harris, 2014; Saccardi, 2014; Wang et al., 2010). It also fosters people to create, discover, and/or produce a new idea or object including the re-arrangement or reshaping of what is already known (Babu \& Reddy, 2013). Moreover, this creative thinking is also a crucial competency for people to produce novel ideas, new approaches, or innovative products which usually benefit individuals andlor social community (Barrow, 2010; Park, Shin, Lee, \& No, 2015).

Additionally, Kaufman and Beghetto (2009) proposed the Four Cs model of creative thinking; mini-c, little-c, pro-C, and big-C. 
Mini-c or the transformative learning is the creative thinking inherent in the learning process. Little-c is a daily problem solving and creative expression. Pro-C is exhibited by a professional in their field but not eminent, and Big-C is reserved for an individual who creates something great in his/ctciher accomplishment (Kaufmann, 2012). The Four Cs models were proposed to differentiate and accommodate the types of creativity which may use to solve daily problem challenges and creative endeavor to initiate prodigious and marvelous results while encountering challenges (Tull, 2014)

Synthetically, creative thinking is the cognitive ability to generate innovative ideas about procedures, services, or products that are novel and effective to solve problems and/or give benefits to the individual/community. It's also revealed that creative thinking is possessed by most people in certain degrees being used in various approaches from daily life problemsolving to significant achievements of individual/community.

Most researchers declaimed fluency, flexibility, originality, and elaboration as the key determinants of creative thinking (Pishghadam \& Mehr, 2011; Sriwongchai et al., 2015; Tateishi, 2011; Tezci et al., 2008). Fluency is the ability to rapidly produce a large number of ideas and consequences or possibilities, and to produce different ideas and hypotheses in related to the problems that engage the mind of the person (Tezci et al., 2008). Flexibility is the ability to look at a topic or a problem from a different perspective and elaboration is the ability to develop and exaggerate an idea (Shively, 2011). Elaboration fleshes out the ideas of working collaborators, carriers and an idea to fruition, or adds contextual details needed to make something real, understandable, or aesthetically pleasing (Shively, 2011). Originality, on the other hand, is the ability to produce ideas that are unique, unusual, and extraordinary (McGregor, 2001; Taylor, 2008).

All of the major factors of creative thinking are closely related to individual's knowledge and competency; creative thinking powerfully assists people to generate innovative knowledge itself and approaches to overwhelm challenges in their professional fields. Moreover, creative thinking should be closely related to imagination because it needs imagination to think, arrange, and visualize various ideas to solve a problem. This correlation is supported by Vygotsky (2004) theories which described that imagination may create various combinations of ideas based on individual's previous experiences. This also explains why there are differences between children and adults' creativity because they have different experiences. Finally, creative thinking is about how people generate a novel idea to give benefit to both the individual and social community. If they know that what they are doing is important for themselves andlor society, it will motivate them to do the action (Bandura, 1986). All the three components when put together will foster creativity as mentioned in the componential model of creativity which states that the more individual's expertise, skills, and task motivation, the more its creativity (Amabile, 1997). Therefore, it can be concluded that educational institutions need to provide indepth knowledge, more experiences, and motivation to support its student's creative thinking improvement.

Three major theories addressing the creative thinking processes have been declared including (1) preparation, exploration, incubation, and verification (Corazza \& Agnoli, 2016; Lau, 2011; Wang et al., 2010); (2) problem definition, idea conceptualization, and architecture/building phase (Harris, 2014); and (3) challenging orthodoxies, harnessing trends, leveraging resources, and understanding needs (Gibson, 2015). Those theories have both similarities and differences, conclusively this paper describes creative thinking process consisted of 3 stages including challenging accepted belief and imagining trends or defining problems, generating and selecting ideas, and demonstrating or testing ideas. 
Firstly, challenging accepted belief happens when people begin to ask skeptical questions that had never been asked before and to challenge deeply entrenched beliefs that had long been taken for granted (Gibson, 2015). For instance, Elon Musk challenging himself to create a spacecraft which make it possible for people to go travelling into space easily, a controversial idea contrasted with the common believe which states that only National Aeronautics and Space Administration (NASA) and Russian Federal Space Agency (RFSA) who capable to bring people rockets into space. Furthermore, creative thinking is might be fostered from an existing problem occurred (Harris, 2014) as well as the attention on the way the world would be or should be in the future (Gibson, 2015). People will able to provide good quality solutions when they can clearly define the problem at the beginning. Moreover, if individual capable for visualizing what will happen in the future, then they can leveraging resources at themselves and the world around them to create and catch new opportunities.

The second stage is generating and selecting an idea, a process to generate some possible new ideas to solve the problem or create new opportunities. During this process, all the material and resources are categorized, reorganized, and weighed from different perspectives, trying to connect ideas and draw conclusions, and coming up with a new and useful idea (Lau, 2011). If various ideas arise, it can be selected using analytical tools such as delphi, voting, or idea criteria tools (Harris, 2014).

Finally, the last stage is demonstrating/testing idea, a process to bring the idea to realization (Harris, 2014) and to check whether the idea really works and can be improved further (Lau, 2011). Creative people do not always come up with successful solution at the first chance, even there are some creative people who failed spectacularly, but they able to learn from their failures and rise above them (Lau, 2011).
According to the theories about creative thinking process, it can be concluded that creative thinking process consists of challenging accepted belief and imagining trends/defining problems, generating \& selecting ideas, and demonstrating/testing ideas. Creative thinking originates with questioning accepted beliefs or routine activities happen around the creative individual, then leads to form a problem need to be solved andlor inspire new insight of the future trend. Simultaneously, the problem defined andlor forthcoming insight forces creative individuals to generate ideas and selects the best one. Finally, the selected idea need to be verified whether it novel, useful, and can be realized or not.

Previous paragraphs discussed creative thinking, a cognitive ability to generate innovative ideas through challenging accepted belief, imagining trends or defining problem, generating and selecting idea, and demonstrating or testing idea which is affected by individual's expertise, experiences, and motivation. While this paragraph will further discuss about some strategies to improve individual's creative thinking in the educational setting.

Previous studies revealed that there are various strategies to improve individual's creative thinking in the educational setting. This paper analyses 4 types of strategies for students' creative thinking enhancement including creativity as a curricular program, an extracurricular program, an independent course, and an integrative course presented in Table 1. Wyke (2013) studying about teaching creativity and innovation at the University of Maine concluded that the curricular program is effective in instructing the knowledge and skills to practice creativity and innovation. The University of Maine offered a minor graduate certificate in Innovation Engineering which consisted 4 core courses including create, communicate, commercialize, and experience courses. While at the Yogyakarta State University, creativity is taught as extracurricular activities where students took 1- 
2 days training and received some materials including creativity development, creative intelligence, creative character transformation, change management, chance creation, and building a creative team (Jumadi et al., 2009). $\mathrm{Wu}$ et al. (2017) identify that this program assists its participants to attain higher academic achievement and get a job faster than students who do not take the training. Table 1 shows the strategies to improve students' creative thinking.

Table 1. Strategies to Improve Students' Creative Thinking

\begin{tabular}{|c|c|c|}
\hline Strategies & Definition & Characteristics \\
\hline $\begin{array}{l}\text { Curricular } \\
\text { program }\end{array}$ & $\begin{array}{l}\text { Creative } \\
\text { thinking } \\
\text { offered as a } \\
\text { major } \\
\text { program at the } \\
\text { university }\end{array}$ & $\begin{array}{l}\text { - Receive both } \\
\text { creative thinking } \\
\text { contents and } \\
\text { improvement } \\
\text { - Take time ( }>1 \\
\text { semester or } 2 \\
\text { years) } \\
\text { - Cost consuming }\end{array}$ \\
\hline $\begin{array}{l}\text { Extra- } \\
\text { curricular } \\
\text { program }\end{array}$ & $\begin{array}{l}\text { Creative } \\
\text { thinking } \\
\text { offered as an } \\
\text { extra- } \\
\text { curricular } \\
\text { activities }\end{array}$ & $\begin{array}{l}\text { - Students receive } \\
\text { both creative } \\
\text { thinking contents } \\
\text { and } \\
\text { improvement } \\
\text { - Need shorter } \\
\text { time than } 3 \text { other } \\
\text { programs } \\
\text { - Voluntarily }\end{array}$ \\
\hline $\begin{array}{l}\text { Creative } \\
\text { Thinking } \\
\text { Education } \\
\text { course }\end{array}$ & $\begin{array}{l}\text { Creative } \\
\text { thinking } \\
\text { offered as a } \\
\text { unit part of } \\
\text { the whole } \\
\text { curriculum }\end{array}$ & $\begin{array}{l}\text { - Students receive } \\
\text { both creative } \\
\text { thinking contents } \\
\text { and } \\
\text { improvement } \\
\text { - Needs more } \\
\text { course credit }\end{array}$ \\
\hline $\begin{array}{l}\text { Integrative } \\
\text { course }\end{array}$ & $\begin{array}{l}\text { Creative } \\
\text { thinking } \\
\text { improvement } \\
\text { strategies are } \\
\text { implemented } \\
\text { on the } \\
\text { teaching- } \\
\text { learning } \\
\text { process }\end{array}$ & $\begin{array}{l}\text { - Students achieve } \\
\text { creative thinking } \\
\text { improvement but } \\
\text { not receive its } \\
\text { theoretical } \\
\text { contents }\end{array}$ \\
\hline
\end{tabular}

Furthermore, Alzoubi et al. (2016) reporting on thinking education where one of the courses taught at Princess Alia University College aimed to familiarize students with creativity and strategies to improve it, revealed that creative thinking education enhances student's creative self-efficacy. Thinking education course consists of the concept of creative thinking, theories explaining creative thinking, creativity and intelligence, creative thinking skills, teaching methods and strategies of creative thinking, stages of creative thinking, characteristics of the creative individual, international programs for creative thinking education, and training activities for enhancing creative thinking (Alzoubi, et al. 2016).

Creativity taught in Universities as an integrative course was found to affect student's creative thinking and performance (Yasin \& Yunus, 2014). Ardian \& Munadi (2015) claimed that there is an interaction between the learning strategy implemented in the learning process and the students' creativity. For instance, Hernandez et al. (2012) experiment about the effect of TRIZ on idea generation shows that it significantly improves variety and novelty of students' ideas creation. Moreover, instructional technology utilization to deliver course contents significantly increases students' creativity level (Eyadat \& Eyadat, 2010). Various strategies such as brainstorming, problem solving, and metaphoric thinking which are integrated into regular courses offered in universities also significantly enhance students' creative thinking or performance (Yasin \& Yunus, 2014).

Curricular programs, extracurricular programs, thinking education courses, and integrative courses as proven strategies to improve individual's creative thinking and performance have its own characteristics. Students may receive the whole set of creativity program including the concepts, major factors, and strategies of creativity improvement through a creativity development program which could be recognized as curricular programs, extracurricular programs, and 
thinking education courses. On the other hand, students seem not receive the complete concepts of creative thinking through joining the integrated course. It means that their creativity is improved but might be they do not understand what creativity is and how to teach creativity to others.

Additionally, based on the time needed for each program, it can be concluded that creative thinking as an extracurricular program requires less time than the other 3 programs. Fewer time needed is an advantage, however this program might be unable to reach all students because most of extracurricular programs are voluntarily activities $(\mathrm{Wu}$, et al. 2017). While curricular program and thinking education courses on creativity might be able to reach all the students but it needs to add more credits to the school curriculum. Conclusively, this article proposes to use curriculum infusion as a strategy to improve students' creative thinking and deliver creativity contents as well.

The term "curriculum" refers to all school's academic program or specific courses that are intended or unintended as providing students with some knowledge and experiences to enhance individual's achievements (Cansever, 2015; Modebelu, 2016; Molnar, 2010; Stone, 2010). Moreover, curriculum infusion is integrating additional concepts, knowledge, and even practical experiences into one or more required courses in a general education presented in Figure 1 (Cook, 2002; White et al., 2010). It has been promoted as an effective strategy in educational reform across several decades (Michigan Department of Education, 2014).

Curriculum infusion provides the opportunities for cooperative instructional strategies among faculty members which are conducive to academic attainment because they are constantly learning, planning, and applying findings from their experiences and joint inquiries (Michigan Department of Education, 2014). Curriculum infusion benefits students by increasing students' knowledge of specific or related issues from various discipline areas, assisting students in making informed decisions on specific substance through scholarly activities, allowing students to actively involved in a teaching-learning process, and assisting students' role as agent of change in the community (The University of Richmond, 2017). Faculty members' benefits are increasing knowledge of specific or related issues from various discipline areas, increasing the creativity of instructional design, contributing to the communities' effort in combating some problems (The University of Richmond, 2017).

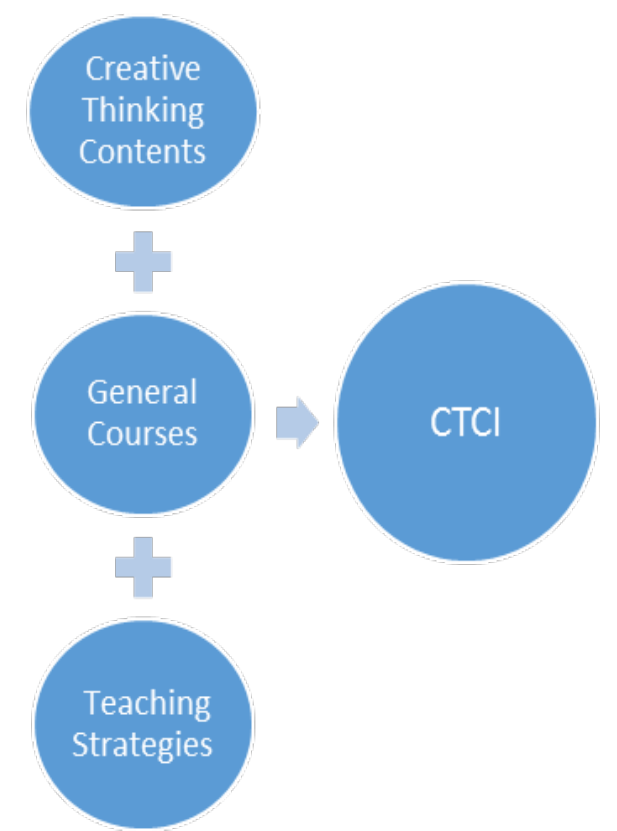

Figure 1. Concepts of Creative Thinking Curriculum Infusion (CTCI)

Curriculum infusion is allowed to infuse important social issues such as substance abuse prevention, discrimination, and sexual harassment into the academic content of a course to enhance the learning environment for students (Lederman et al., 2007; Roles \& Recovery, 2017). Creative thinking as an essential competency to success in this globalization and competitiveness era should be taught to all youngsters as a part of their future career and business preparation. Teachers' education program provides an opportunity to reach all of the students to get this creative thinking contents by trained the future teacher with creative thinking's theories, contents, and 
strategies. Therefore, creative thinking curriculum might be infused into regular courses for the future and in service teacher at the teacher education program institution.

Creative Thinking Curriculum Infusion model consists of 4 major components: objectives, contents, teaching strategies, and assessment methods of creative thinking presented in Figure 2. The following paragraph discusses the objectives and contents of CTCI, and the implementation of CTCI at teacher's education program.

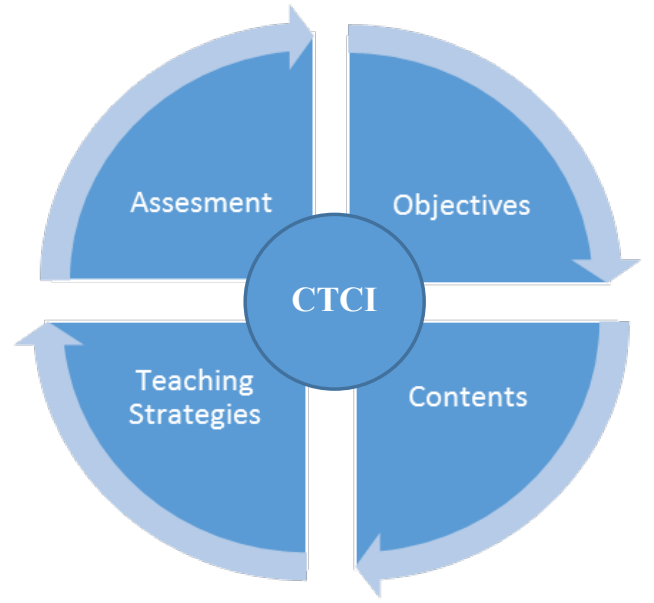

Figure 2. Development of Creative Thinking Curriculum Infusion
Creative thinking curriculum infusion purports to integrate creative thinking contents into regular offered courses at teacher education program in universities. Among its functions is to improve students' creative thinking. Furthermore, it also fosters students to identify and to explain creative thinking theories, understand the benefits of creative thinking for future career and business, implement strategies to improve individual's creative thinking, implement creative thinking into daily life and professional fields, understand the policies about creativity and creative industry.

Creative thinking curriculum infusion purports to deliver creative thinking contents and improve students' creative thinking as well. There are some materials related to creative thinking theories, improvement strategies, and its implementation on the daily life and professional career presented in Table 2.

Table 2. Objectives and Contents of Creative Thinking Curriculum

\begin{tabular}{ll}
\hline \multicolumn{1}{c}{ Objective } & \multicolumn{1}{c}{ Content } \\
\hline Understanding creative thinking & $\begin{array}{l}\text { Definition of creative thinking } \\
\text { Major contents of creative thinking } \\
\text { Major functions of creative thinking } \\
\text { Success stories of creative people on their professional } \\
\text { career and business } \\
\text { for future career and business }\end{array}$ \\
$\begin{array}{l}\text { Understanding and implementing strategies } \\
\text { to improve individual's creative thinking }\end{array}$ & $\begin{array}{l}\text { Creative thinking process } \\
\text { Strategies to improve individual's creative thinking }\end{array}$ \\
$\begin{array}{l}\text { Implementing creative thinking into daily } \\
\text { life and professional fields }\end{array}$ & $\begin{array}{l}\text { Four Cs of creative thinking } \\
\text { Case study/project }\end{array}$ \\
$\begin{array}{l}\text { Understanding policies about creativity } \\
\text { Understanding and generating new ideas of } \\
\text { creative industries }\end{array}$ & Catent submission procedures \\
\hline
\end{tabular}

The creative thinking curriculum contents are developed based on its objectives and the fact that creative thinking is a crucial competencies to be successful in this globalization era (AMA, 2010; Flynn, 2014; Higgins, 2014; Hilton, 2015), current situation of higher education in Indonesia which revealed that students receive $90 \%$ of hard skills and $10 \%$ of soft skills (Sailah, 2008), and analyses of existing creative thinking curriculum at some universities. There are some universities which provide creative thinking programs such as the 
University of Massachusetts, the University of Maine, and the Yogyakarta State University.

Creative thinking development at the universities is trained and taught to students in various programs. For example, Critical and Creative Thinking Student Handbook [CCT Student Handbook] (2017) of the University of Massachusetts mentions that this university provides creative thinking for master program, the University of Maine delivers it as an additional courses program (Wyke, 2013), and the Yogyakarta State University teaches its students through extracurricular activities ( $\mathrm{Wu}$, et al., 2017).

Furthermore, almost all courses in the university are appropriate and suitable for curriculum injection program (Gordie center, 2017). In general, courses of the Indonesian Universities which provide teacher education program consist of 3 major group courses comprising compulsory courses, pedagogical courses, and specific courses based on its professional major program.

Compulsory courses are provided by all universities throughout Indonesia because they have to provide these courses in its curriculum. Students at universities should take this courses as a requirement to finish their studies. Compulsory courses including Religion, Citizenship Education, English, Social and Culture Education, Indonesian language, Statistics, Pancasila, Entrepreneurship, and Field Studies or a Community Service Program. Moreover, pedagogical courses consist of courses to train the students to be skilled teachers such as curriculum design, teaching strategies, students' assessment, and psychology. There are also specific courses based on its department or major such as courses specific for engineering education program, automotive engineering education program, mathematics education program, etc.

Creative thinking curriculum infusion program proposes to select compulsory courses as a medium to give students theories, improvement strategies, and how to implement creativity in daily life and professional career. It was selected because compulsory courses are provided by all universities in Indonesia which makes it possible to reach all college's students. It is also taught by selected teachers in each university which makes it more pertinent to train the designated teachers than all the teachers in each university, and it also has objectives which are appropriate with the creative thinking curriculum contents. For example, Indonesian Language course objectives are to teach the students how to systematically write a paper, communicate ideas to public and academic society, document the paper, and avoid plagiarism. Its objectives might be matched with the creative thinking curriculum objective to generate new ideas and implement creative thinking in the daily life.

A teaching strategy is a method that will be used to attain the objectives of the teaching learning process (Alcina, 2011). To achieve creative thinking curriculum infusion objectives, some teaching methods are combined with strategies to improve individual's creative thinking. There are some approaches might be used to improve students' creative thinking such as brainstorming, problem solving, brain writing, computer aided teaching, lateral thinking, and metaphoric thinking (Harris, 2014; Lau, 2011). Those strategies are combined and mixed with other teaching approaches such as lecturing, industrial visiting, problem based learning, and project based learning to get greater achievement on students' creative thinking. For example, teachers might ask the students to visit a successful businessman on creative industry, do some interviews, present to other students, and use brainstorming to discuss the benefits of creative thinking for their future career and business, and how to reach it. Hence, it can be concluded that creative thinking infusion program should use various active learning teaching strategies to get greater effect on students' creative thinking improvement.

Assessment methods are the effective approaches to measure the students' performance and teaching-learning results for 
educational quality control and even improvement (Alcina, 2011). Several creative thinking assessments have been proposed to identify creativity performance including a test of creative thinking, creative product measurement, and a self-assessment test. The Torrance Test of Creative Thinking (TTCT) is the most frequently used instrument in measuring creativity specifically related to divergent thinking in both children and adults population of studies (Ma, 2009; Yasin \& Yunus, 2014). Students' responses are evaluated based on fluency, flexibility, originality, and elaboration.

Another method of measuring creativity is by determining whether the product generated is creative or not (Yasin \& Yunus, 2014). This method is known as Consensual Assessment Technique (CAT), which was first introduced by Teresa Amabile in 1982 (Baer \& McKool, 2009). Assessment of some creative product or group of products done by a panel of experts in the related field (Kaufman et al., 2008). Baer \& McKool (2009) noted that the most valid assessment on creativity of an idea or product in any field is based on the combined opinions of experts in the fields.

On some occasions, it is possible to obtain information about people's creativity from the responses they provide to questions about themselves and their behavior (Treffinger et al., 2002). Some writers in the creativity literature have argued, quite seriously, that the best way to determine whether or not people are creative is, in fact, simply to ask them (Abbot, 2010; Kauffman, 2012). Several of the assessment instruments and resources to measure individual's creativity including creativity assessment packet (William, 1980), creativity attitude survey (Schaeffer, 1971), Creative behavior inventory (Hocevar, 1980).

Based on the aforementioned descriptions, the creative thinking curriculum infusion program might be measured through a test of creativity, creative product measurements, or self-assessment. The type of measurement is selected alignment with the curriculum objective and content. For example, creative product measurement is used to assess students' creativity on the creative project development course and self-assessment scale to evaluate student's general creative thinking at the first semester and the end semester.

\section{CONCLUSION}

This paper intensively proposes the curriculum infusion model to improve students' creative thinking in the teacher education program; this model infuses creative thinking skills into courses for learners to understand its theories, improvement strategies, and implementations into daily life and their professional issues. Creative thinking is crucial, almost required, competency which should be enhanced in all courses in whole educational settings: it should be integrated to spin-in and spin-out through all courses taking the curriculum infusion model. Consequently, this paper provides the following suggestions in order to implement the creative thinking curriculum infusion: (1) Infuse creative thinking curriculum into compulsory courses offered in universities because it provides opportunities for all students to take the courses, (2) implement various creative thinking improvement strategies for the teaching learning activities, and (3) use a creative thinking self-assessment scale to measure students' creative thinking. Moreover, the proposed methods should be applied to attain its empirical confirmation for proving its effectiveness.

\section{REFERENCES}

Abbot, D.H. 2010. Experiencing Creative SelfEfficacy: A Case Study Approach to Understand Creativity in Blogging. Journal of Media and Communication Studies. 2. 8, 170-175

Alghafri, A. S. R., \& Ismail, H. N. B. 2014. The Effects of Integrating Creative and Critical Thinking on Schools Students' 
Thinking. International Journal of Social Science and Humanity. 4.6, 518

Alzoubi, A. M., Al Qudah, M. F., Albursan, I. S., Bakhiet, S. F., \& Abduljabbar, A. S. 2016. The Effect of Creative Thinking Education in Enhancing Creative Self-Efficacy and Cognitive Motivation. Journal of Educational and Developmental Psychology. 6.1, 117

American Management Association (AMA). 2010. Executives Say the $21^{\text {st }}$ Century Requires More Skilled Workers

Ardian, A. \& Munadi, S. 2015. Pengaruh Strategi Pembelajaran Student-Centered Learning dan Kemampuan Spasial terhadap Kreativitas Mahasiswa. Jurnal Pendidikan Teknologi dan Kejuruan. 22.4, 454-466

Babu, M.R.N. \& Reddy, V.D. 2013. Creativity among B.Ed. Students of Nandyal Town In Relation to Their Achievement Motivation. Indian Journal of Health and Wellbeing. 4. 1, 180-183

Baer, J., \& McKool, S. S. 2009. Assessing Creativity Using the Consensual Assessment Technique. In Handbook of Research on Assessment Technologies, Methods, and Applications in Higher Education (65-77). IGI Global

Barrow, L.H. 2010. Encouraging Creativity with Scientific Inquiry. Creative Education. 1, 1-6

Baygin, M., Yetis, H., Karakose, M., \& Akin, E. 2016, September. An Effect Analysis of Industry 4.0 to Higher Education. In Information Technology Based Higher Education and Training (ITHET), 2016 15th International Conference on (1-4). IEEE

Cansever, B. A. 2015. Education Paradigm and Globalization. In Handbook of Research on Enhancing Teacher Education with Advanced Instructional Technologies (228-243). IGI Global
Cook, B. G. 2002. Inclusive attitudes, strengths, and weaknesses of pre-service general educators enrolled in a curriculum infusion teacher preparation program. Teacher Education and Special Education. 25. 3, 262-277

Dagget, B. 2014. Addressing Current and Future Challenges in Education: Lessons Learned from the Nation's Most Rapidly Improving and Transformative Schools. Rexford, NY: International Center for Leadership Education

Demir, B. K., \& Isleyen, T. 2015. The Effects of Argumentation Based Science Learning Approach on Creative Thinking Skills of Students. Educational Research Quarterly. 39. 1, 49

Flynn, T. T. 2014. Do They Have What It Takes: A Review of the Literature on Knowledge, Competencies and Skills Necessary for 21st Century Public Relations Practitioners in Canada. Canadian Journal of Communication. 39.3

Ford, C. M., \& Gioia, D. A. 2000. Factors Influencing Creativity in the Domain of Managerial Decision Making. Journal of Management. 26. 4, 705-732

Groff, J. 2013. Technology-rich Innovative Learning Environments. OCED CERI Innovative Learning Environment Project, 1-30

Guilford, J.P. 1950. Creativity. American Psychologists. 5, 444-454

Harris, L.V.A. 2014. Idea engineering: creative thinking and innovation. New York: Momentum press

Hendrickson, R. M., Lane, J. E., Harris, J. T., \& Dorman, R. H. 2013. Academic Leadership and Governance of Higher Education: A Guide for Trustees, Leaders, and Aspiring Leaders of Twoand Four-year Institutions. Stylus Publishing. LLC 
Hilton, M. 2015. Preparing Students for Life and Work. Issues in Science and Technology. 31.4, 63

Hsiao, H.S., Chang, C.S., Lin, C.Y., \& Hu, P.M. 2014. Development of Children's Creativity and Manual Skills within Digital Game-Based Learning Environment. Journal of Computer Assisted Learning, 30, 377-395

Karpova, E., Marcketti, S. B., \& Barker, J. 2011. The Efficacy of Teaching Creativity: Assessment of Student Creative Thinking before and after Exercises. Clothing and Textiles Research Journal. 29. 1, 52-66

Kaufman, J. C. \& Beghetto, R.A. 2009. Beyond Big and Little: The Four C Model of Creativity. Review of General Psychology 13. $1,1-12$

Kaufman, J.C. 2012. Counting the Muses: Development of the Kaufman Domains of Creativity Scale (K-DOCS). Psychology of Aesthetics, Creativity, and the Arts. 6.4, 298-308

Knight, J. 2003. GATS, Trade and Higher Education: Perspective 2003-Where Are We? The Observatory on Borderless Higher Education, London

Lau, J.Y.F. 2011. An Introduction to Critical Thinking and Creativity: Think More, Think Better. New Jersey: John Wiley \& Sons, Inc.

Lederman, L. C., Stewart, L. P., \& Russ, T. L. 2007. Addressing College Drinking through Curriculum Infusion: A Study of the Use of Experience-Based Learning in the Communication Classroom. Communication Education. 56.4, 476-494

McGregor, G.D. Jr. 2001. Creative Thinking Instruction for a College Study Skills Program: A Case Study. Dissertation Published by ProQuest LLC. UMI Number: 3027933

Michigan Department of Education. 2014. Curriculum Integration Research: Re-
Examining Outcomes and Possibilities for the $21^{\text {st }}$ Century Classroom. Michigan: USA

Modebelu, M.N. 2016. Curriculum Development Models for Quality Educational System. Educational Leade rship and Administration: Concepts, Methodologies, Tools, and Applications: Concepts, Methodologies, Tools, and Applications, 262

Molnar, M. L. 2010. Arts-based ServiceLearning: A Curriculum for Connecting Students to Their Community. The University of Arizona

Nozari, A. Y., \& Siamian, H. 2014. The Effects of Problem-Solving Teaching on Creative Thinking among District 2 High School Students in Sari City. Materia sociomedica. 26.6, 360

Park, J.S., Shin, S.Y., Lee, S.M., \& No, S.R. 2015. Human Resource Management Practices and Organizational Creativity: The Role of Chief Executive Officer's Learning Goal Orientation. Social Behavior and Personality. 4396, 899-908

Petrie, N. 2011. Future Trends in Leadership Development. Center for Creative Leadership White Paper. 5, 5

Pishghadam, R., \& Mehr, F.J. 2011. Learner Creativity and Performance in Written Narrative Tasks. World Journal of Education. 1.2, 115-125

Saccardi, M. 2014. Creativity and Children's Literature: New Ways to Encourage Divergent Thinking. California: ABCCLIO

Sailah, I. 2008. Pengembangan Soft Skills di PerguruanTinggi. Tim Kerja Pengembangan Direktorat Jenderal Pendidikan Tinggi: Pendidikan Tinggi

Sdouh, W. M. 2013. The Effect of Using the Strategies of Brainstorming and Computer Education in Academic Achievement and the Development of Creative Thinking Skills of Sixth Grade 
Students in Jordan and Their Attitudes towards Learning Mathematics.European Scientific Journal, ESJ. 9.13

Shively, C. H. 2011. Grow Creativity!. Learning \& Leading with Technology, $38.7,10-15$

Sriwongchai, A., Jantharajit, N., \& Chookhampaeng, S. 2015. Developing the mathematics learning management model for improving creative thinking in Thailand. International Education Studies, 8.11, 77-87

Stone, M. K. 2010. A Schooling for Sustainability Framework. Teacher Education Quarterly. 37.4, 33-46

Taylor, L.D. 2008. Creative Thinking and Worldviews in Romania. Dissertation published by ProQuest LLC. UMI Number: 3311919

Tezci, E., Karaca, D., \& Sezginsoy, B. 2008. The Study of Reliability and Validity of Creative Materials. The Turkish Online Journal of Education Technology. 7.1

Treffinger, D. J., Young, G. C., Selby, E. C., \& Shepardson, C. 2002. Assessing Creativity: A Guide for Educators. National Research Center on the Gifted and Talented

Tull, C.M. 2014. An Experiment in Facilitating Creative Thinking in Second Degree Accelerated Nursing Students. Dissertat ion Published by ProQuest LLC. UMI Number: 3629004

University of Richmond. 2017. Curriculum Infusion.

Wang, S.C., Peck, K.L., \& Chern, J.Y. 2010. Difference in Time Influencing Creativity Performance between Design and Management Majors. Int. J Technol Des Educ. 20, 77-93

White, S., Park, Y. S., \& Cordero, E. D. 2010. Impact of Curriculum Infusion on College Students' Drinking Behaviors. Journal of American college health. 58.6, 515-522

Wu, M., Siswanto, I., Haryana, K, \& Sampurno, Y. G. 2017. A Comprehensive Evaluation on the Creativity Enhancement Program: A Case Study of Yogyakarta State University Indonesia. International journal of Scientific Research and Innovative Technology. 4.3

Wu, M., Siswanto, I., \& Ko, C. 2017. The Influential Factors and Hierarchical Structure of College Students' Creative Capabilities-An Empirical Study in Taiwan. Thinking Skills and Creativity, 26, 176-185

Yasin, R.M. \& Yunus, N.S. 2014. A MetaAnalysis Study on the Effectiveness of Creativity Approaches in Technology and Engineering Education. Asian Social Sciene, 10.3, 242-252 